\title{
THE BACTERIOLOGICAL QUALITY, FAT AND COLLAGEN CONTENT OF Minced MEAT
}

\author{
Hassan, M. Gad Elrab*,Hanan Moustafa EL-Lawendy and Mona T. Raslan
}

*Animal Health Research Institute food Hygiene (Sohag Branch),(Zagazig branch)

\begin{abstract}
Fifty samples of minced meat were collected from different localities at Sohag Governorate. The collected samples were transported to the laboratory on ice box to be examined bacteriologically for A.P.C., Bacillus cereus count, Staphylococcus aureus and Streptococcus faecalis. The mean values of the aforementioned microorganisms were $8.1 \times 10^{4} ; 2.1 \times 10^{6} ; 8.1 \times 10^{4}$ and $5 \times 10^{3}$ microorganism/gram for the examined samples respectively. Moreover, other bacterial species were isolated and identified. Fat, collagen and moisture contents in the examined samples ranged from 16.5 - 30.3\% for fat; $1.7-4.1 \%$ collagen while moisture ranged from $53-68.1$ in the examined samples .Measures to improve product quality were discussed. The public health importance of existed microorganisms as well as the recommended methods to improve the sanitary status of the product to prevent their rapid spoilage were mentioned.
\end{abstract}

\section{INTRODUCTION}

The bacteriological quality of meat at retail is relatively poorly documented in the scientific literature .Concern that minced meat might be a cause of food borne illness has prompted interest in the numbers and types of bacteria commonly occurring in it . Minced meat is a very common and popular processed meat product manufactured from lower 
value minced meat to produce higher value products. Food additives are used to accomplish certain function and altered flavor. Where it is a good source of protein and of low price. The meat is easily cured and the high protein content provides good caloric value. Also processed products from meat are cheap. Mahmoud et al., (2004) stated that the bacteriology of meat and products are very scantly.

Isolation and enumeration of the microorganisms present in foods usually demands preliminary treatment of samples to release into a liquid medium those microorganisms present that may be included within the food (Anavella, 2001).

Meat is subjected to contamination with several types of microorganisms, from different sources from the time of slaughter till consumption. Such contamination may render the product of inferior quality or even unfit for consumption, thus; resulting in economic losses and at times may constitute a public health hazard. Human food poisoning is commonly associated with bacteria originating form animal sources, in most cases; infection is contracted directly by eating meat and meat products. Such contamination may occur in the slaughter houses or during processing and handling or post cooking.

So this study was done to investigate the bacteriological quality of fat and collagen content of minced meat.

\section{MATERIAL AND METHODS}

Fifty random samples from minced meat each $250 \mathrm{gm}$ weight were collected from different localities in Sohag city and transferred to the laboratory under strict hygienic measures where they were subjected to bacteriological examination. 
Minced meat homogenate was prepared according to Thatcher and Clark (1975). Total colony count (A.P.H.A., 1972), Bacillus cereus count (Barraued et al., 1967), Staphylococcus aureus count (Thatcher and Clark 1978) and Total Streptococcus faecalis count (Efthymiou and Joseph 1974) were carried out. Isolation of other members of enterobacteriaceae organisms was done according to Cruickshank (1972). Bacillus cereus was identified according to Cowan and Steel (1974). Biochemical tests for identification of the isolated were carried reactions according to Cowan and Steel (1974).

\section{Moisture and fat determination:}

Ten samples were collected from minced meat at retailed shops three times consequently with a week intervals, samples were thoroughly mixed and sub-sampled for moisture and fat determination according to Roberts et al., (1980). For moisture, 12-15g of sample was weighed to the nearest milligram, freeze-dried and finally dried to constant weight in a vacuum oven at $70^{\circ} \mathrm{C}$.

For free fat, 8- $10 \mathrm{~g}$ of sample was freeze-dried and extracted for $8 \mathrm{~h}$ in a Soxhlet apparatus using $40^{\circ}-60^{\circ}$ petroleum spirit. The extracted fat was expressed as a percentage of the fresh weight of the sample. Although there are two appropriate BSI/ISO methods for 'total fat' or 'free fat', the meat trade prefers the free fat method because it involves less manipulation of the sample. The total fat method can give values up to $\mathrm{Ca} .1 \%$ higher than the free fat method, but where fat levels are $\mathrm{Ca}$. $15-25 \%$ the difference is relatively unimportant.

\section{Collagen content:}

It is measured according to Hudson et al (1986). 


\section{RESULT AND DISCUSSION}

Total number of viable aerobic bacteria in food is generally used to determine food quality; this producer is based on the assumption that each microbial cell in a sample will form a visible separate colony when mixed with agar medium and permitted to grow (Ward, 1977).

Table (1) showed that the mean Aerobic plate count in examined samples ranged from $4.6 \times 10^{3}$ to $3.2 \times 10^{5}$ with a mean value $8.1 \times 10^{4}$ cfu/gram it indicates the contamination of ingredients due to unsanitary conditions during handling, processing and distribution as well as the influence of high storage temperature that accelerate the existing organisms. Nearly similar finding were noticed by Hudson et al., (1986) and Mahmoud et al., (2004).

These microorganisms can cause off flavors and physical defects in foods. Their presence indicates a high potential for spoilage during extended storage. (Griffiths et al., 1981). Most of these microorganisms are destroyed by mild heat treatment, but some heat-resistant types such as some species of Bacillus and Clostridium. The presence of psychrotrophic microorganisms in heat-processed foods implies postprocessing contamination, which act as a sources of heat-resistant proteolytic and lipolytic enzymes.

The results obtained in table (1) pointed out that all minced meat samples from ground meat were high in Bacillus cereus count which ranged from $6 \times 10^{3}$ to $3.4 \times 10^{6}$ with a mean value of $2.1 \times 10^{6} \mathrm{cfu} / \mathrm{gram}$ . Higher results were obtained by Mahmoud et al., (2004). 
Bacillus cereus is a highly pathogenic microorganism and may cause food poisoning they can grow well at a wide rang of temperature $\left(25-75^{\circ} \mathrm{c}\right)$ and at $\mathrm{pH}$ value from 6-7. Their spores are very resistant to heat and its growth is inhibited at $\mathrm{pH}$ lower than 4 . This species is highly lipolytic, saccharolytic and proteolytic. It may be present on flour, milk, dairy products, rice, chicken, spices, and herbs. Only total absence of this species is normally accepted by legal regulations (Cliver, 1990).

Also Staphylococcus aureus counts ranged from $6 \times 10^{4}$ to $2 \times 10^{5}$ $\mathrm{cfu} /$ gram with a mean value $8.1 \times 10^{4}$ in the examined sample respectively. The presence of $S$. aureus in a number of examined samples suggested that the poor personal hygiene of food handlers as the organisms originate from suppurating lesion or from the nostril of a carrier Elwi (1994).

Staphylococci produce heat-resistant toxins that act at the digestive level. There are seven kinds of enterotoxins, A, B, Ch $\mathrm{C}_{2}, \mathrm{C}_{3}, \mathrm{D}$, and $\mathrm{E}$. Toxins $\mathrm{A}$ and $\mathrm{D}$ are more frequently present in food intoxication. Staphylococcus aureus may cause skin infection (acne). Staphylococci could be present in, e.g., dairy, meat, sausages, fish, and eggs.

Generally it is noticed, from the obtained results that all bacterial counts were highe. Bacillus cereus indicated that the environmental contamination ,handlers mincing machines are the main source for its presence and also spices may be another source (Ahmed, 2002). It is of basic importance to the manufacture of all processed meat is the selection of proper raw material. Quality of these meat as determined by their chemical and microbiological qualities should be high for it is certainly a truism a finished product can be of no higher quality than the ingredients it contain (Person and Tauber, 1984). They are usually kept 
in special, dry premises away from the workers, in which they can preweighed, blended and packed into plastic bags in the proportions required for product formulation. One of the most important consequences of failure to protect all non meat ingredients is contamination with dirt, excreta from rodents, birds or other animals and infestation with insects (Cano Munoz, 1992).

Streptococcus faecalis count (in table 1) ranged from $4.2 \times 10^{2}$ to 3 $\mathrm{x} 10^{4}$ with a mean value of $5 \times 10^{3} \mathrm{cfu} / \mathrm{gram}$ a higher microbes count in the examined samples due to unsanitary measures, improper handling, (Mahmoud, 2004).

Bacillus cereus also recorded higher percentage bacterial species isolated in different percentages from all the examined samples (25) were citrobacter (16), Proteus (17), Klebsiella (12), S. aureus (6) and Str faecals (11). (Table 2). The public health and spoilage significance of these bacterial species reveal the risk on the consumer and bad keeping quality (Elmaghraby, 2002; Ahmed, 2002; Mahmoud et al., 2004 and Maha et al., 2008).

The results in table (3) detected that fat content ranged from $16.5-$ $30.3 \%$, The high fat content of some minced beef has received adverse publicity, yet the meat trade is sometimes represented to be most reluctant to support the imposition of legally enforceable standards for fat content. A chosen standard must be attainable by good commercial practice. Rapid and accurate control of fat levels is only possible, however, by the use of expensive instrumental methods; for example, the Foss-Let fat analyzer $(\boldsymbol{A O A C}, \mathbf{1 9 8 0})$ and the CEM analytical system (Bostian et al., 1985). 
Collagen content ranged from $1.7-4.1$ and moisture from $53-$ $68.1 \%$. Laboratory studies show that mean values of the collagen of muscles from which the muscle sheath arid external aggregates of connective tissue have been trimmed $\mathrm{He}$ between $\mathrm{Ca} 0.5 \%$ in better quality meat such as the loin and $\mathrm{Ca} 3.5 \%$ in poorer quality meat such as the shin (Bendall, 1967). Commercially butchered joints from beef carcasses showed mean collagen values from $1.9 \%$ (2.3\% wet fat free) in the better quality joints to $4.4 \%$ (4.8\% wet fat free) in the shin (Casey et at., 1985). Note that the collagen content of the mince samples obtained by analysis, when expressed as a percentage of wet tissue, will be affected by the amount of fat in the sample, which, in turn, depends on the amount of fat left on the original cuts of beef. Any added fatty tissue will itself contain varying amounts of collagen. It would therefore be difficult to relate the analytical collagen values for beef minces to any particular commercial cut.

Nearly similar results reported by Hudson et al., (1986) who found that fat content of minced beef ranged from $17-25 \%$ while the collagen in the mince at retail ranged from $1.4 \%$ to $4.4 \%(1.5 \%$ to $5.1 \%$ in a wet fat free basis). Ishrak et al., (2004) suggested that the use of lactic acid bacteria would help preserving fresh minced meat for extended period at $22^{\circ} \mathrm{C}$, and has a drastic reduction in SPC coliforms enterococci and Staphylococci. It could be concluded that proper handling, application of sanitary measures, package and storage are the causes for lower bacterial count in the retailed minced meat. 
Hassan, M. Gad Elrab et al.,

Table (1): Statistical analysis of bacterial count of examined minced meat samples $(n=50)$.

\begin{tabular}{|l||c||c||c||}
\hline \multicolumn{1}{|c||}{ Microorganisms } & Minimum & Maximum & Mean \\
\hline \hline Aerobic plate count & $4.6 \times 10^{3}$ & $3.2 \times 10^{5}$ & $8.1 \times 10^{4}$ \\
\hline Bacillus cereus count & $6 \times 10^{3}$ & $3.4 \times 10^{6}$ & $2.1 \times 10^{6}$ \\
\hline Staphylococcus aureus count & $6 \times 10^{4}$ & $5.2 \times 10^{5}$ & $8.1 \times 10^{4}$ \\
\hline Streptococcus faecalis count & $4.2 \times 10^{2}$ & $3 \times 10^{4}$ & $5 \times 10^{3}$ \\
\hline \hline
\end{tabular}

Table (2): The incidence of isolated microorganisms from the examined samples.

\begin{tabular}{|l||c||c||}
\hline \multicolumn{1}{|c|}{ Isolates } & +ve & $\%$ \\
\hline \hline Bacillus cereus & 25 & 50 \\
\hline Klebsiella pneumonae & 12 & 24 \\
\hline Citrobacter freundii & 16 & 32 \\
\hline Proteus spp. & 17 & 34 \\
\hline Coagulase + ve Staphylococcus aureus & 6 & 12 \\
\hline Streptococcus faecalis & 11 & 22 \\
\hline
\end{tabular}

Table (3): Percentage fat, moisture and collagen in the examined samples

\begin{tabular}{|c||c|c|c||c|c|c||c|c|c||}
\hline \multirow{2}{*}{ shop } & \multicolumn{3}{|c||}{ Fat content (\%) } & \multicolumn{3}{c||}{ Collagen (\%) } & \multicolumn{3}{c||}{ Moisture content (\%) } \\
\cline { 2 - 10 } \multicolumn{1}{|c|}{} & \multicolumn{3}{|c|}{ Visit } & \multicolumn{3}{c||}{ Visit } & \multicolumn{3}{c||}{ Visit } \\
\hline \hline \multirow{2}{*}{1} & 1 & 2 & 3 & 1 & 2 & 3 & 1 & 2 & 3 \\
\hline 2 & 22.2 & 24.9 & 31.1 & 3.9 & 2.6 & 1.9 & 58.3 & 61.2 & 60.5 \\
\hline 2 & 23.4 & 22.7 & 24.8 & 1.7 & 2.8 & 3.5 & 59.6 & 66.2 & 62.9 \\
\hline 3 & 30.3 & 27.4 & 21.2 & 3.9 & 3.3 & 2.9 & 68.3 & 56.4 & 59.2 \\
\hline 4 & 29.7 & 22.2 & 17.6 & 2.6 & 3.8 & 4.1 & 59.6 & 57.2 & 54.9 \\
\hline 5 & 21.3 & 20.7 & 24.8 & 1.8 & 3.2 & 2.8 & 62.3 & 64.2 & 53 \\
\hline 6 & 19.3 & 15.8 & 16.9 & 4.4 & 3.8 & 3 & 60.1 & 62.3 & 58.4 \\
\hline 7 & 28.1 & 22.3 & 18.4 & 2.8 & 3.7 & 4.1 & 59.2 & 59.7 & 57.1 \\
\hline 8 & 19.8 & 24.1 & 17.6 & 3.1 & 2.7 & 2.1 & 62 & 60.1 & 56.4 \\
\hline 9 & 19.0 & 22.1 & 20.4 & 2.4 & 4.2 & 3.8 & 60.3 & 59.2 & 54 \\
\hline 10 & 22.8 & 30.1 & 27.4 & 1.9 & 2.8 & 3.2 & 68.1 & 64.2 & 57.1 \\
\hline \hline
\end{tabular}

Kafrelsheikh Vet. Med. J. Vol. 7 No. 1 (2009) 


\section{REFERENCES}

- Ahmed Dalia, M.S. (2002): Hygienic evaluation of camel meat Ph.D. Thesis, Faculty of Vet. Med., Zagazig University.

- Ahmed, I.M. (1991): Hygienic quality of marketed ready to eat meat. M.V. Thesis, Fac. of Vet. Med., Zagazig University.

- American Public Health Association "APHA" (1972): Standard Methods for Examination of Dairy Products. Inc. $13^{\text {th }}$ Ed. New York.

- Anavella, G. Herrera (2001): Food microbiology protocols. Totowa N.J.

- AOAC(1980): manualfor AOAC., $13^{\text {th }}$ Edn paragraph 24006, AOACW ashington, DC.

- Barroued c,kitchellAG,Labots H,Reuter Gand SimonesB (1967): Standrdization of total aerobic countin meat and meat products Fleshchwirtschaft47, 1313

- Bendall, J. (1967): Journal of the science of food and agriculture, 18, 553-8.

- BostinaM.,Fish D.,Webb,n. andArey J.(1985): J.Ass. Off. Anal. Chem., 68 (5) 87680 Casey, J. C., Crosland, A. R. and Patterson, rR. L. S. (1985) Meat science,12,189-203.

- Cliver, D.O. (1990): Foodborne Diseases, Academic Press, San Diego, CA.

- Cowan, S.T. and Steel, K.J. (1974): Manual for Identification of Medical Bacteria, $2^{\text {nd }}$ Ed. Cambridge: Cambridge University Press. Gary, W.E. Back.

- Cruickshank, R. (1972): Handbook of Bacteriology, 10 ${ }^{\text {th }}$ Ed. S.L. Livingstone Ltd Edinburgh and London. 
- Efthymiou, C.L. and Joseph, S.W. (1974): Development of selective enterococcus media based on manganese deficiency, sodium azide and alkaline phosphate. Appl. Microbiol. 28: 411.

- El-Maghraby Omayma, M. (2002): Experimental trials to minimize microbial contamination of camel's meat. Ph.D. Thesis, Fac. of Vet. Med., Cairo University.

- Griffiths, M.W.;Phillips, J.D. and Muir, D.D. (1981): Thermostability of proteases and lipases from a number of species of psychrophilic bacteria of dairy origin. J. Appl. Bacterial. 50: 289-303.

- Hudson, W.R.; Roberts, T.A.; Crosland, A.R. and Casey, J.C. (1986): The bacteriological quality, fat and collagen content of minced beef at retail level. Meat Science, 17: 139-156.

- Ishrak, K.; Mohamed, F. and Ahmed, T.H. (2004): Extending shelf life of fresh minced camel meat at ambient temperature by lactobacillus dibruecki subsp. Electronic J. of Biotechnology. 7 (3):246-252

- Maha M. Sameer; Enas M. Sami and Elshorbagy, I.M. (2008): Hygienic quality of ready to eat cooked meat in Sharkia province. $9^{\text {th }}$ Vet. Med. Zag. Conference. $191-200$.

- Mahmoud, Y.A. and Fatma, H.M. Ali (2004): Risk assessment of rice kofta formed from camel meat. Assuit Vet. Med. J. 50 (100): ???

- Person, A.M. and Tauber, F.W. (1984): Processed meat. $2^{\text {nd }}$ Ed.

- Roberts, T.A.; Britton, C.R. AND Hudson, W. R. (1980): Journal of Hygiene, Cambridge, 85: 211-17.

- Thatcher, F.S. and Clark, D.S. (1975): Microorganisms in food I. International Committee on Microbiological Specifications of Foods. Univ. of Toronto Press, Toronto and Buffalo, Canada.

- Thatcher, F.S. and Clark, D.S. (1978): Int. Commit. Microbiol. Specif. Food, Microorganisms in Foods I, Academic Press, New York.

- Ward, D.R. (1997): Basic food microbiology. Food Microb. Control FDA. 


\section{الحالة البكتيريولوجية ومحتوي الدهن والكولاجين للحم المفروم بمحافظة سوهاج}

حسن محد جاد الرب" حنان مصطفي / للا وندي مني طلعت رسلان معهل بحوث صحة الحيوان صحة الأغذية - معمل سوهاج" / والزقازيق

أجريت هذه الدراسة لمعرفة الحالة الصحية ومحتوي الدهن و الكو لاجين في اللحوم المفرومة بسوهاج، حيث تم تجميع 50عينة لفحها بكتريولوجياً. تم نقل العينات للمعل في ثلاجة حفظ العينات بأسرع وقت ونم فحص العينات لتحديد العد الكلي للميكروبات الهو ائية وميكروب الباسيلس سيرس و العنقودي الذهبي و الميكروب السبحي.

وكان متوسط العد الكلي لهذه البكتريا فى العينات التي تم فحصها لتلك الميكروبات 8.1 ات

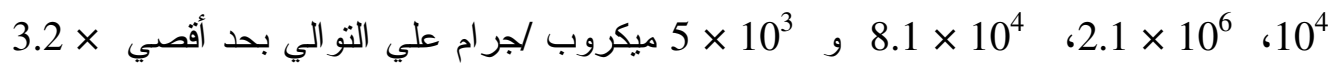

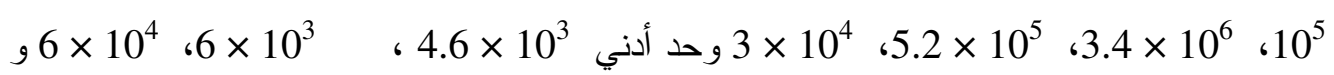
4.2 × $10^{2}$

كما نم عزل ميكروبات الباسيلس سيرس و الكليبيلا نيموني وسيتروباكتر فرونداي وبعض أنواع البروتيس و العنقودي الذهبي بنسب تكر ارية مختلفة .

كما نم جمع 30عينة من المحلات من اللحوم المفرومة علي ثلاث مرات أسبوعياً لتحديد محتوي الدهون و الكو لاجين والرطوبة.ووجد أن نسبة الدهن في العينات المفحوصة نراوحت من

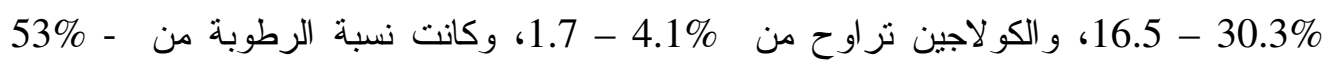
$68.1 \%$.

هذا وقد ثم مناقثنة الأهمية الصحية لهذه الميكروبات و التوصيات المطلوبة لتحسين حالة المنتج وسلامته و الحفاظ على صحة المستهلك. 